\title{
Alternative interpretations of some earliest Ediacaran fossils from China
}

Heyo Van Iten, Juliana De M. Leme, Antonio C. Marques, and Marcello G. Simões

Acta Palaeontologica Polonica 58 (1), 2013: 111-113 doi: http://dx.doi.org/10.4202/app.2011.0096

In a letter to Nature (February, 2011), Xunlai Yuan and collaborators recorded carbon compression fossils from black

shales of the Lantian Formation (Ediacaran), southern Anhui Province, South China. The new fossils, described

under five morphological types (Types A to E), exhibit degrees of morphological differentiation suggesting that they

were multicellular eukaryotes. Some of the Lantian macrofossils were interpreted as algae, but others are of unknown affinities. For reasons noted in this discussion, Type A fossils attracted our particular attention, and we suggest an alternative interpretation of their affinities. According to our view, some of them (at least those with three faces and no globose holdfast at their base) may represent conulariid cni-darians or close medusozoan relatives. The undistorted organism probably was a three-sided cone in life. We believe that our suggested alternative interpretations of the anatomy and affinities of the fossils in question can be useful in guiding future research on the oldest currently known fossil assemblage of multicellular organisms.

Heyo Van Iten [vaniten@hanover.edu], Department of Geology, Hanover College, Hanover, IN 47243, USA; Juliana de M. Leme [leme@ usp.br], Department of Sedimentary and Environmental Geology, University of São Paulo, 05580-080, São Paulo, SP, Brazil; Antonio C. Marques [marques@ib.usp.br], Department of Zoology, University of São Paulo, Rua do Matão, Travessa 14, 101, 05508-090, São Paulo, SP, Brazil; Marcello G. Simões [profmgsimoes@ gmail.com], Department of Zoology, São Paulo State University, 18.618-000, Botucatu, SP, Brazil.

This is an open-access article distributed under the terms of the Creative Commons Attribution License (for details please see creativecommons.org), which permits unrestricted use, distribution, and reproduction in any medium, provided the original author and source are credited. 
FoF Full text $(186.3 \mathrm{kB})$ 